\title{
Seasonal activity patterns and diet divergence of three sympatric Afrotropical tortoise species (genus Kinixys)
}

\author{
Luca Luiselli \\ F.I.Z.V., and Centre of Environmental Studies "Demetra", via Olona 7, I-00198 Rome, Italy: E-mail: \\ lucamlu@tin.it
}

Keywords: tortoises, Kinixys belliana nogueyi, Kinixys erosa, Kinixys homeana, food niche, Niger Delta, Nigeria

\begin{abstract}
Three species of hinge-back tortoises (Kinixys belliana nogueyi, Kinixys erosa, Kinixys homeana) are found in simpatry in the rainforests of the Niger Delta, southern Nigeria (west Africa). The seasonal activity patterns and food habits of these tortoises are studied in the present paper. $K$. erosa and $K$. homeana have similar activity patterns, with peaks occurring during the wet season. Kinixys belliana was found only during the wet months. There was no evidence of any specific effect of humidity of the air on their activity intensity, and it seems likely that, more than absolute values of air humidity, the crucial factor to force tortoises into high activity is the sudden change between dry days and very wet days at the onset of the rainy season (end of March - early April). K. homeana was significantly more active in the early phase of the wet season. Common items, which were consumed by all three predator species, were: plant matters, fruits and berries, fungi, Oligochaeta, and Gastropoda Pulmonata, whereas Araneidae were also consumed by all species, but much more rarely. Common prey items, which were consumed by $K$. homeana and not by $K$. erosa were: Coleoptera larvae, Dermaptera, and termites. $K$. homeana appeared more generalist than $K$. erosa, and the respective diets diverged considerably both in dry and in wet seasons. On the other hand, the diets of $K$. erosa and $K$. belliana were more similar (at least in wet season).
\end{abstract}

\section{Contents}

$\begin{array}{ll}\text { Introduction } & 211 \\ \text { Materials and methods } & 212 \\ \text { The study species } & 212 \\ \text { Study areas and methods } & 212 \\ \text { Results } & 213 \\ \text { Seasonal activity patterns } & 213 \\ \text { Food habits } & 214 \\ \text { Discussion } & 216 \\ \text { Acknowledgements } & 218 \\ \text { References } & 118\end{array}$

\section{Introduction}

Although some groups of reptiles (notably lizards and snakes) have become very popular subjects for community ecology studies (e.g., Scott and Campbell, 1981; Pianka, 1973, 1975, 1986; Barbault, 1977, 1991; Toft, 1985; Luiselli et al., 1998, 2002), chelonians have been largely overlooked in this respect (Scott and Campbell, 1981). Indeed, relatively few information is available on the organization and the forces structuring the communities of sympatric chelonians, and in most cases the available data concern with freshwater turtles, whereas very few data are available for communities of terrestrial species (Lagler, 1943; Legler, 1976; Vogt, 1981; Williams and Christiansen, 1981; Jackson, 1988; Vogt and Guzman, 1988; Moll, 1990; Stone et al., 1993; Hailey, 1995; Sammartano, 1995; Teran et al., 1995; Kennett and Tory, 1996; Baard, 1997; Allanson and Georges, 1999; Luiselli et al., 2000; Pritchard, 2001).

The forest habitats of west and central Africa house a rich chelonian fauna (Villiers, 1958; Iverson, 1992) which can be an ideal target for studies on community ecology and species' interactions. However, the few papers published up to now on terrestrial hinge-back tortoises (genus Kinixys) analysed aspects of their conservation ecology (Lawson, 2000; Luiselli, 2003; Luiselli et al., 2003), morphometrics (Lawson, 2001), or ecological correlates of their local distribution (Luiselli et al., 2000). No specific emphasis was placed on community ecology studies of terrestrial species.

The Niger Delta region (southern Nigeria, West 
Africa) is characterized by the presence of three sympatric species of terrestrial hinge-back tortoises (Kinixys belliana nogueyi, Kinixys erosa, and Kinixys homeana, cf. Luiselli et al., 2000; Luiselli, 2003). It is particularly noteworthy, as it is very unusual to find all these species sympatric in other regions of Africa, due to their different ecological and habitat requirements (Ernst and Barbour, 1992).

My aims in the present study are to investigate the seasonal activity patterns and the food habits of these three tortoise species in sympatric populations, their variations in relation to season, and the potential for inter-specific competition for food which could eventually regulate their coexistence dynamics. In addition, my data are compared to food data for other Kinixys species which have been carefully studied during the recent years (Hailey, 1995, 1997, 1998; Hailey et al., 1997, 1998, 2001).

\section{Materials and methods}

\section{The study species}

Detailed statistical studies, based on logistic regression predictive models, of the habitat requirements and distribution of the three Kinixys species in the Niger Delta are presented in Luiselli et al. (2000). Based on this study, it resulted that $K$. belliana is the rarest of the three species, and is found only in a few sites between the upper Orashi and upper Sambreiro River courses, with open forest patches, clearings and bushy edges. $K$. homeana is the most common and widespread of the three species, and its presence is statistically linked to the presence of secondary swamp-forest, secondary dry forest, and mangrove formations along river banks. $K$. erosa is less common than $K$. homeana, and its presence is statistically linked to the presence of secondary swamp-forest. $K$. homeana and $K$. erosa are similar in terms of habitat requirements, and their local distributions widely overlap, although $K$. homeana is more easily found than $K$. erosa in nearly every sites where the two species are sympatric.

\section{Study areas and methods}

Data were collected, from September 1996 to January 2002, in the eastern side of the Niger Delta (Bayelsa, Rivers, and Anambra States). A detailed description of the study sites where data were collected is presented in Luiselli et al. (2000).

Tortoises were searched for by means of different surveying procedures: (i) random searching along all forest micro-habitats potentially inhabited by tortoises, (ii) pitfalls with drift fences checked every day, and (iii) examination of specimens captured by local people and generally traded in bush-meat markets (e.g., see Luiselli et al., 1998, 2003b; Lawson, 2000), which are generally found along the main roads and in the riverine villages (Ojonugwa, 1986).

Random searching was done during 711 different days, 338 during the wet season (May to September), and 373 during the dry season (October to April), whereas bush-meat markets were visited on a regular basis (at least twice on each month). All the bush-meat markets situated along the courses of the rivers Sambreiro (= Sombreiro) and Orashi, and those in the vicinities of the urban centres of Yenagoa, Sagbama, Port Harcourt, Peterside, Bonny, Obrikom, Oguta, Ahoada, Abonnema, and Degema, were visited (Luiselli et al., 2003).

Every tortoise, whether free-ranging or traded, was examined to species, sex, plastron length, and body weight. Free-ranging tortoises were permanently individually marked by unique sequences of notches filed into the marginal scutes, and their food habits were determined by faeces analysis. Faeces samples were obtained from animals that defecated on handling, and stored in jars of $10 \%$ formalin. Each sample of faeces was placed in a shallow dish of water, and the presence of different food items was noted. The samples were then divided into four parts: those recognisable as vascular plants, fungi, invertebrates, and others. The faecal pellets were then dried and examined as in Hailey et al. (1997). Tortoises, offered for sale, which were already dead at the time of examination, were dissected for any food item in the stomach. Moreover, the sellers (which normally were also the hunters) were interviewed to learn more about the 
time of capture and the habitat of capture of the traded specimens (see also Luiselli et al., 2003).

All data were statistically analysed by STATISTICA (versions 5,0, for Windows) PC+ package, with all tests being two-tailed and alpha set at $5 \%$. To avoid statistical problems due to "pseudo-replication" of the data (cf. Licht et al., 1966; Mathur and Silver, 1980; Hurlbert, 1984), I took food data only once from each tortoise individual, i.e. the recaptured individuals were never used again for data recording. To avoid problems in mixing data from both stomach contents of dissected specimens (in which it is often possible to count the exact numbers of items eaten by each tortoise) and faecal pellets of living specimens (in which it is often impossible to do it), I always considered for my analyses the total number of specimens containing a given prey type, and not the total number of prey items.

\section{Results}

\section{Seasonal activity patterns}

The monthly numbers of Kinixys specimens observed at the study areas (cumulating data from both markets and the field) are given in Figure $1(K$. homeana) and Figure 2 ( $K$. erosa). No figure is given for $K$. belliana due to the too small sample examined: only 8 specimens were found, all in wet season (4 in April, 3 in May, 1 in June). There were significant month-by-month variations in the numbers of observed specimens (= above-ground activity intensity) in both $K$. homeana and $K$. erosa (for $K$. homeana - males: $\chi^{2}=349.11$, df $=11, P$ $<0.00001$, females: $\chi^{2}=340.10$, df $=11, P<$ 0.00001 , juveniles: $\chi^{2}=58.24, \mathrm{df}=11, P<0.00001$; for $K$. eros $a$ - males: $\chi^{2}=72.01, \mathrm{df}=11, P<$ 0.00001 , females: $\chi^{2}=45.12, \mathrm{df}=11, P<0.00001$, for juveniles $\chi^{2}$ value is not calculated due too the small sample examined), and most of the specimens of both species were found during the wet season months (Figures 1 and 2). However, there was no effect of monthly relative humidity (Figure 3 ) on the numbers of observed specimens of both $K$. homeana (for males: $F_{8.2}=0.71, P=0.700$; for females: $F_{8.2}=0.51, P=0.796$ ) and $K$. erosa (for males: $F_{8,2}=0.59, P=0.755$; for females: $F_{8,2}=0.34$, $P=0.887)$.

In inter-specific comparisons (after having pooled males, females and juveniles), it resulted that, although both species had activity peaks during the wet months, there were significant differences in

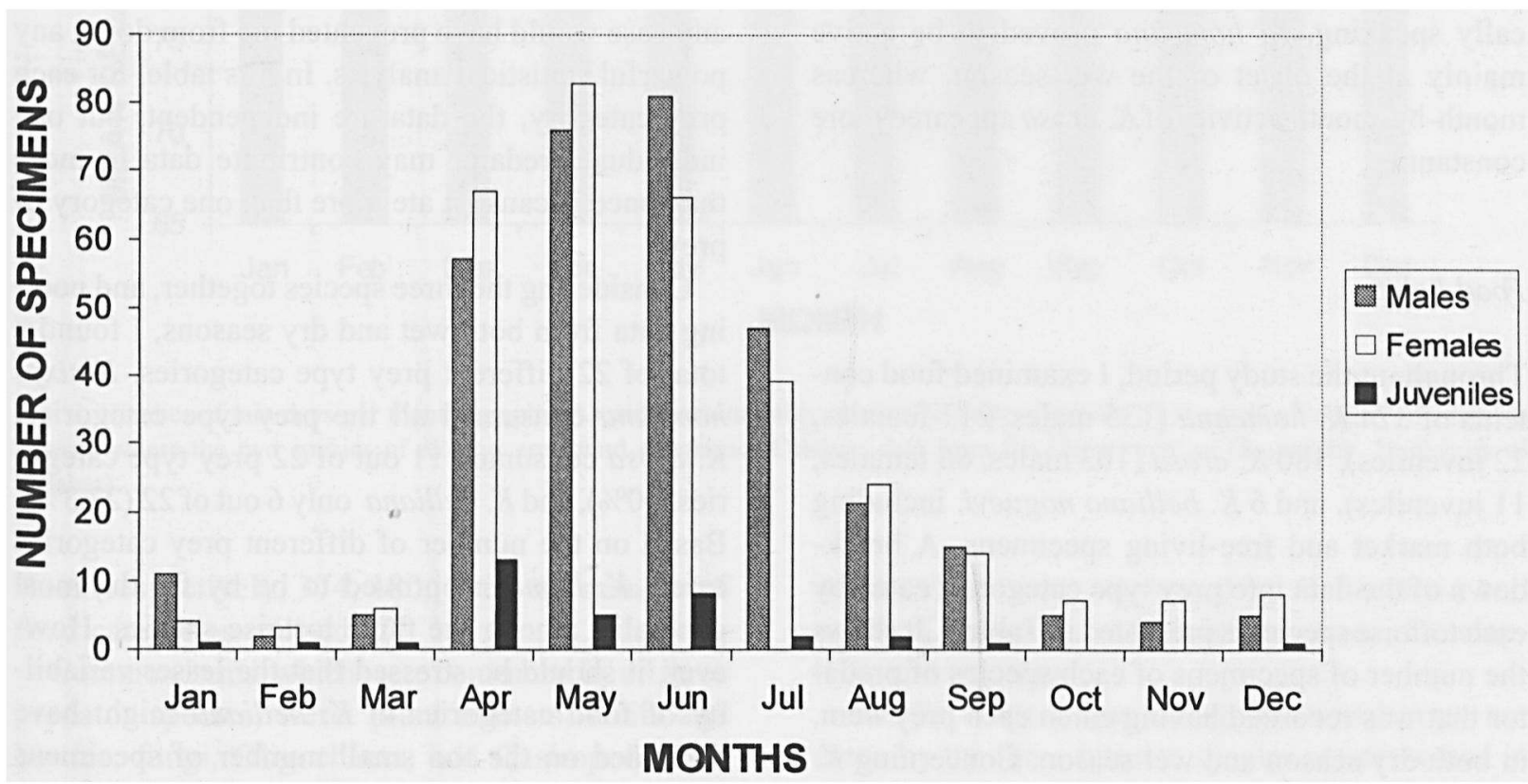

Fig. 1. Monthly numbers of observed specimens of Kinixys homeana in the Niger Delta, Nigeria. 


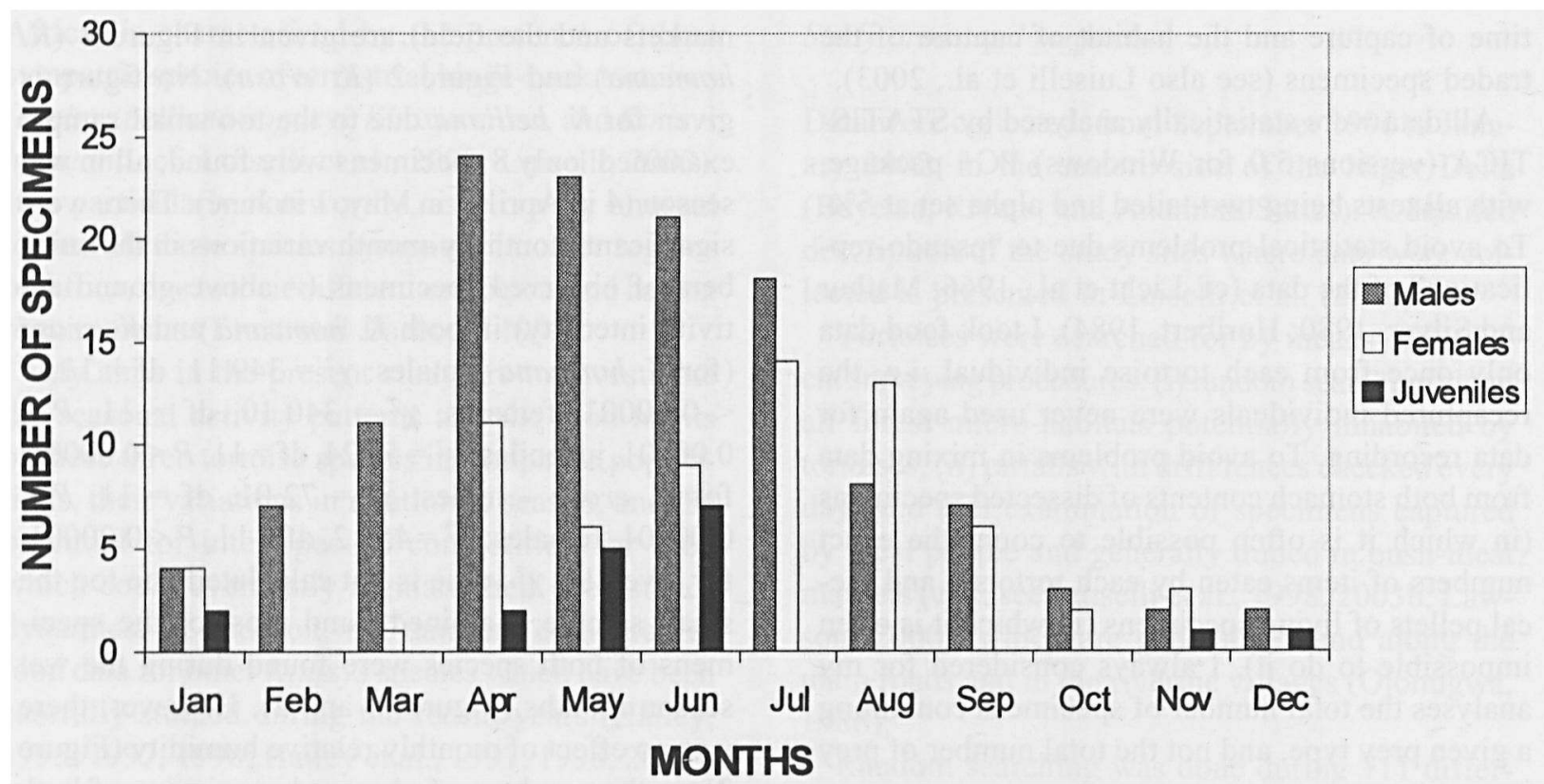

Fig. 2. Monthly numbers of observed specimens of Kinixys erosa in the Niger Delta, Nigeria.

terms of monthly numbers of observed specimens (observed versus expected $\chi^{2}=89.132$, $\mathrm{df}=11$, $P<0.000001)$. In this regard, $K$. homeana was found active particularly in the early phase of the wet season (April, May and June), and $K$. erosa in the late phase of the wet season. Therefore, practically speaking, $K$. homeana proved to be active mainly at the onset of the wet season, whereas month-by-month activity of $K$. erosa appeared more constant.

\section{Food habits}

Throughout the study period, I examined food contents of $374 \mathrm{~K}$. homeana (135 males, 217 females, 22 juveniles), $180 \mathrm{~K}$. erosa (103 males, 66 females, 11 juveniles), and $6 K$. belliana nogueyi, including both market and free-living specimens. A breakdown of the data into prey type categories eaten by each tortoise species is presented in Table 1. It shows the number of specimens of each species of predator that was recorded having eaten each prey item, in both dry season and wet season. Concerning $K$. belliana, samples were collected only during the wet season. Data for both males and females, in $K$. homeana as well as in $K$. erosa, were cumulated after having tested that the two sexes did not differ significantly in terms of taxonomic dietary composition (in all cases, at least $P>0.3$ at $\chi^{2}$ test). Data for both sexes of $K$. belliana are cumulated due to the too small sample examined, which in any case would have prevented me from doing any powerful statistical analysis. In this table, for each prey category, the data are independent, but one individual predator may contribute data to more than once because it ate more than one category of prey.

Considering the three species together, and pooling data from both wet and dry seasons, I found a total of 22 different prey type categories. Kinixys homeana consumed all the prey type categories, $K$. erosa consumed 11 out of 22 prey type categories $(50 \%)$, and $K$. belliana only 6 out of $22(27.3 \%)$. Based on the number of different prey categories eaten, $K$. homeana proved to be by far the most generalist among the three tortoise species. However, it should be stressed that the lesser variability of food categories in $K$. belliana might have depended on the too small number of specimens examined in comparison to the other two species. Indeed, there was an apparent effect of the sample 
A

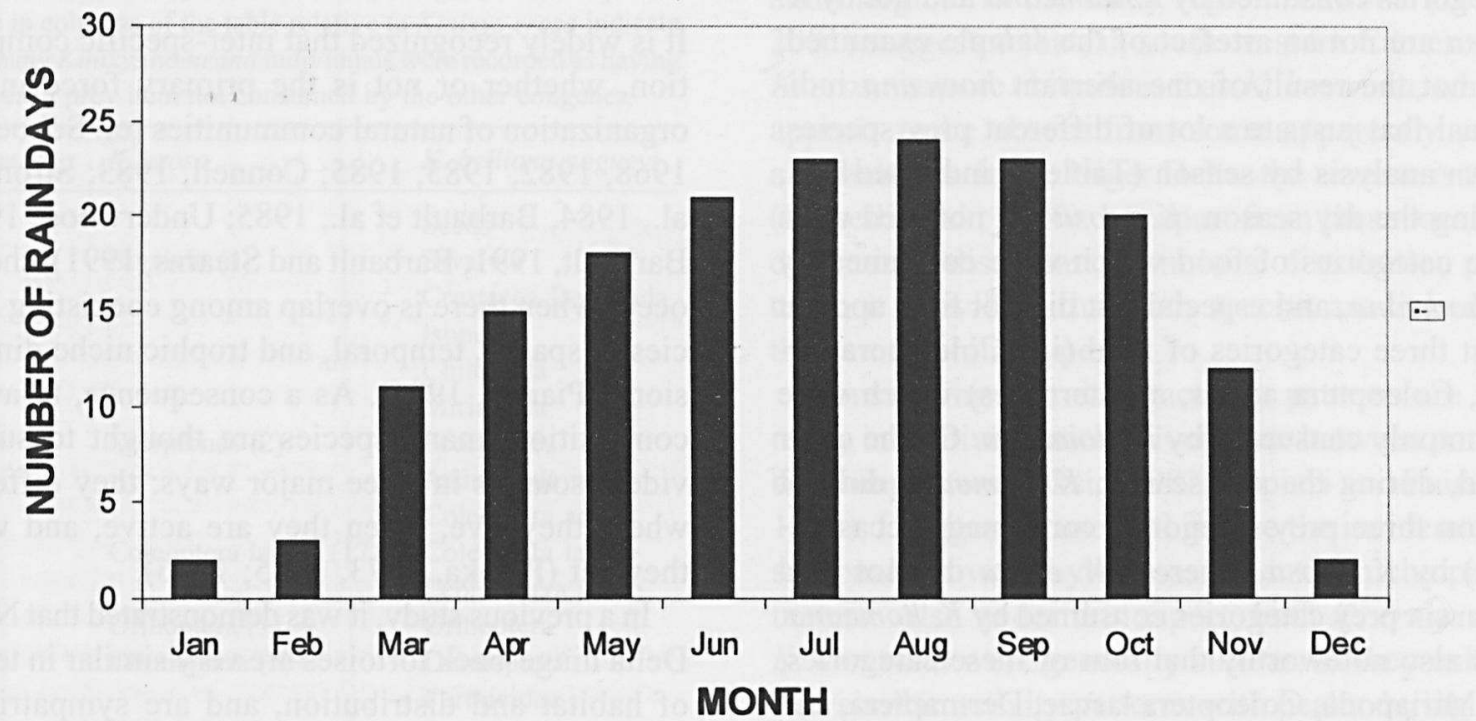

B

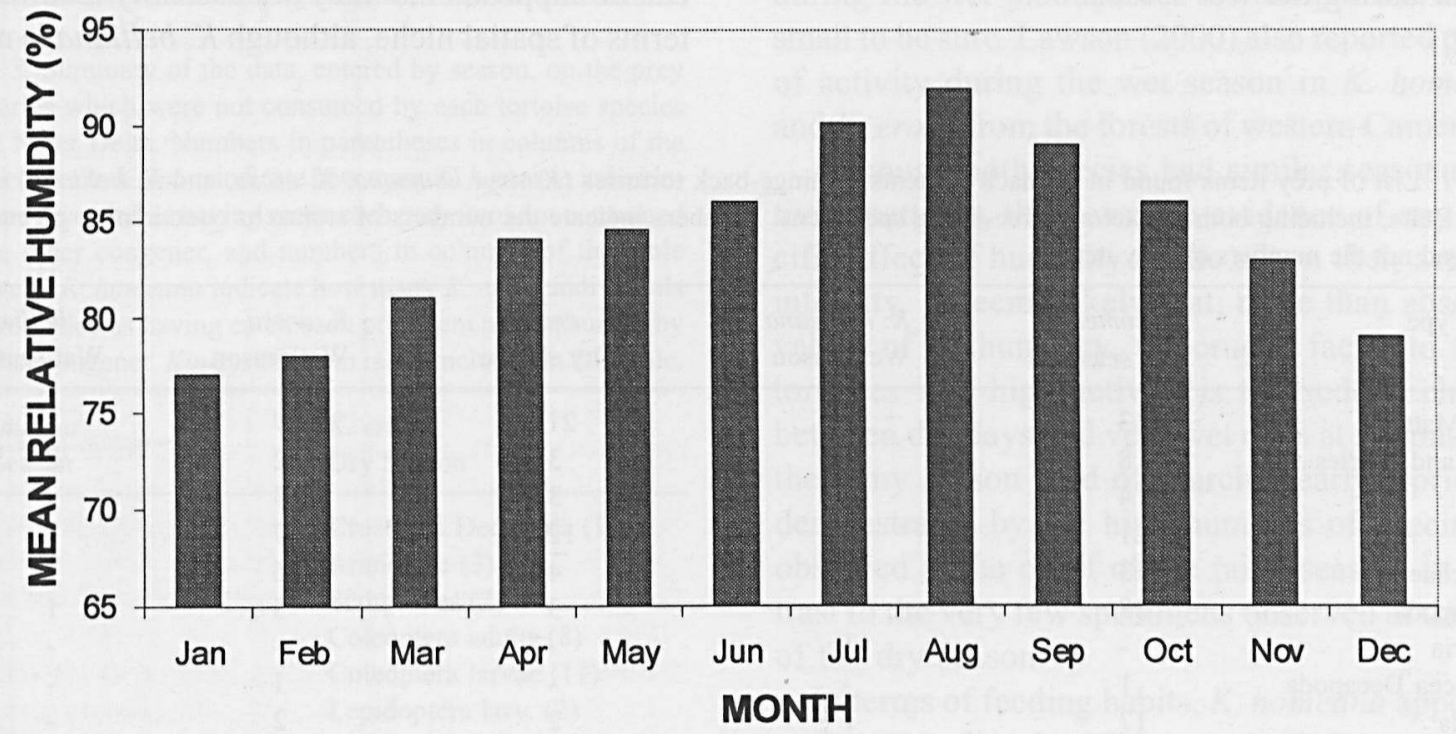

Fig. 3. Number of rain days per month (graphic A) and mean monthly relative humidity (graphic B) at a typical locality of southern Nigeria where the two species of Kinixys are found sympatric (Calabar; data from the Department of Geography, University of Calabar).

sizes (respectively, 374, 180,6) on the number of food categories utilised $(22,11,6)$.

Common items, which were consumed by all three predator species, were: plant matters, fruits and berries, fungi, Oligochaeta, and Gastropoda Pulmonata, whereas Araneidae were also consumed by all species, but much more rarely. Common prey items, which were consumed by $K$. homeana and not by $K$. erosa were: Coleoptera larvae, Dermaptera, and termites.

The list of prey type categories which were not eaten by the three tortoise species are presented in Table 2. These data permit to notice easily (i) the much wider choice of prey consumed by $K$. homeana 
compared to $K$. erosa, and (ii) that the extra prey categories consumed by $K$. homeana and not by $K$. erosa are not an artefact of the sample examined, i.e. not the result of one aberrant homeana individual that just ate a lot of different prey species.

An analysis by season (Table 3 ) indicated that, during the dry season, $K$. erosa did not feed upon nine categories of food which were consumed by $K$. homeana, and especially it did not feed upon at least three categories of food (i.e. Coleoptera larvae, Coleoptera adults, and termites) which were commonly consumed by $K$. homeana. On the other hand, during the wet season, $K$. homeana did not eat on three prey categories consumed (occasionally) by $K$. erosa, whereas $K$. erosa did not feed upon six prey categories consumed by $K$. homeana. It is also noteworthy that four of these categories, i.e. Miriapoda, Coleoptera larvae, Dermaptera, and termites, were important food sources for $K$. homeana during the wet season.

\section{Discussion}

It is widely recognized that inter-specific competition, whether or not is the primary force in the organization of natural communities (cf. Schoener, 1968, 1982, 1983, 1985; Connell, 1983; Strong et al., 1984, Barbault et al., 1985; Underwood, 1986; Barbault, 1991; Barbault and Stearns, 1991), should occur when there is overlap among coexisting species in spatial, temporal, and trophic niche dimensions (Pianka, 1986). As a consequence, to avoid competition, many species are thought to subdivide resources in three major ways: they differ in where they live, when they are active, and what they eat (Pianka, 1973, 1975; 1986).

In a previous study, it was demonstrated that Niger Delta hinge-back tortoises are very similar in terms of habitat and distribution, and are sympatric in many forest areas (Luiselli et al., 2000). Thus, it can be supposed that they are basically identical in terms of spatial niche, although $K$. belliana is more

Table 1 . List of prey items found in stomach contents of hinge-back tortoises (Kinixys homeana, K. erosa, and $K$. belliana) in the Niger Delta, including both market and free-living specimens. Numbers indicate the numbers of stomachs containing a given food type, and not the numbers of prey items.

\begin{tabular}{|c|c|c|c|c|c|}
\hline Prey Type & $\begin{array}{l}K . \text { homeana } \\
\text { Dry season }\end{array}$ & $\begin{array}{l}K . \text { homeana } \\
\text { Wet season }\end{array}$ & $\begin{array}{l}K . \text { erosa } \\
\text { Dry season }\end{array}$ & $\begin{array}{l}K . \text { erosa } \\
\text { Wet season }\end{array}$ & $\begin{array}{l}K . \text { belliana } \\
\text { Wet season }\end{array}$ \\
\hline Plant Matters & 33 & 27 & 21 & 17 & 4 \\
\hline Fruits and Berries & 8 & 6 & 3 & 2 & 2 \\
\hline Seeds & 4 & 3 & 3 & 3 & - \\
\hline Fungi & 21 & 13 & 12 & 7 & 2 \\
\hline Oligochaeta & 13 & 7 & 4 & 6 & 1 \\
\hline Gastropoda & 48 & 7 & 3 & 3 & 1 \\
\hline Bivalvia & - & 1 & - & - & - \\
\hline Crustacea Decapoda & 1 & - & - & 1 & - \\
\hline Isopoda & 17 & 7 & 2 & 2 & - \\
\hline Chilopoda & 11 & 5 & 3 & 1 & - \\
\hline Miriapoda & 16 & 11 & 1 & - & - \\
\hline Araneidae & 3 & - & - & 1 & 1 \\
\hline Scorpiones & 2 & - & - & - & - \\
\hline Arthropoda ind. & 15 & 9 & 2 & - & - \\
\hline Coleoptera adults & 8 & 4 & - & 1 & - \\
\hline Coleoptera larvae & 11 & 6 & - & - & - \\
\hline Lepidoptera larv. & 2 & - & - & 1 & - \\
\hline Orthoptera & 1 & - & - & - & - \\
\hline Dermaptera & $\cdot 1$ & 4 & - & - & - \\
\hline Formicidae & - & 1 & - & 1 & - \\
\hline Termites & 8 & 4 & - & - & - \\
\hline Poultry (scavenging) & - & 1 & - & - & - \\
\hline EMPTY STOMACHS & 42 & 71 & 38 & 21 & 0 \\
\hline
\end{tabular}


Table 2. Summary of the data on the prey categories which were not consumed by each tortoise species. Numbers in parentheses in columns of the table relative to Kinixys erosa indicate how many Kinixys homeana individuals were recorded as having eaten each prey item not consumed by the other congener.

\begin{tabular}{lll}
\hline K. homeana & K. erosa & K. belliana nogueyi \\
\hline & Seeds \\
& Bivalvia (1) & Bivalvia \\
& Crustacea Decapoda \\
& Isopoda \\
& Chilopoda \\
& Miriapoda \\
Scorpiones (2) & Scorpiones \\
& Arthropoda ind. \\
& Coleoptera adults \\
& Coleoptera larvae (17) & Coleoptera larvae \\
& Lepidoptera larv. \\
& Orthoptera \\
Dermaptera (5) & Dermaptera \\
& Formicidae \\
Termites (12) & Termites \\
Poultry (scavenging) (1) & Poultry (scavenging) \\
\hline
\end{tabular}

Table 3. Summary of the data, entered by season, on the prey categories which were not consumed by each tortoise species in the Niger Delta. Numbers in parentheses in columns of the table relative to $K$. erosa indicate how many $K$. homeana individuals were recorded as having eaten each prey item not consumed by the other congener, and numbers in columns of the table relative to $K$. homeana indicate how many $K$. erosa individuals were recorded as having eaten each prey item not consumed by the other congener. Kinixys belliana is not included in this table.

\begin{tabular}{ll}
\hline $\begin{array}{l}\text { K. homeana } \\
\text { Dry Season }\end{array}$ & $\begin{array}{l}\text { K. erosa } \\
\text { Dry Season }\end{array}$ \\
\hline & Crustacea Decapoda (1) \\
& Araneidae (3) \\
& Scorpiones (2) \\
& Coleoptera adults (8) \\
& Coleoptera larvae (11) \\
& Lepidoptera larv. (2) \\
& Orthoptera (1) \\
& Dermaptera (1) \\
& Termites (8) \\
\hline K. homeana & K. erosa \\
Wet season & Wet season \\
\hline Crustacea Decapoda (1) & \\
& Bivalvia (1) \\
& Miriapoda (11) \\
Araneidae (1) & Coleoptera larvae (6) \\
Lepidoptera larv. (1) & Dermaptera (4) \\
& Termites (4) \\
& Poultry (scavenging) (1) \\
\hline
\end{tabular}

linked to open bush, and so appears extremely rare and marginal in the study region. Lawson (2000, 2001) suggested that, in south-western Cameroon, $K$. erosa is more ubiquitous than $K$. homeana, which appears to be absent from some apparently suitable habitats. In the Niger Delta, the reverse is true (Luiselli et al., 2000), but apart from these locallydetermined discrepancies in local distribution patterns, it is evident that both species are linked to the same habitat types.

Considering that daily activity patterns are not really indicative of niche divergence between potential competitors (Jaksic, 1982; Capizzi and Luiselli, 1996), I suggest to use in this case the incidence of seasonal activity rhythms as potential niche parameters. Also under this aspect, both $K$. erosa and $K$. homeana were generally similar, as they exhibited similar activity patterns with peaks during the wet season. Kinixys belliana was also found only during the wet months, but the sample size is too small to be sure. Lawson (2000) also reported peaks of activity during the wet season in $K$. homeana and $K$. erosa from the forests of western Cameroon.

Although both species had similar seasonal activity patterns, there was no evidence of any specific effect of humidity of the air on their activity intensity. It seems likely that, more than absolute values of air humidity, the crucial factor to force tortoises into high activity is the sudden change between dry days and very wet days at the onset of the rainy season (end of March - early April), as demonstrated by the high numbers of specimens observed at the onset of the rainy season, in contrast to the very few specimens observed at the end of the dry season.

In terms of feeding habits, $K$. homeana appeared more generalist than $K$. erosa, and the respective diets diverged considerably both in dry and in wet seasons. Although most of the absent food items can be explained by smaller sample sizes for $K$. erosa, it is likely that the most biologically significant differences are the absence of Coleoptera larvae, Dermaptera and termites, which may indicate that $K$. homeana feeds more in leaf litter and rotting wood, or be due to its smaller body size. The diets of $K$. erosa and $K$. belliana were more similar (at least in wet season), but their ecological coexistence is perhaps facilitated by the different micro-habitat characteristics (belliana is found only 
in drier micro-habitats, whereas erosa lives in very wet micro-habitats, cf. Luiselli et al., 2000). Contrasting $K$. homeana with $K$. erosa, it perhaps that their inter-specific competition is reduced not only by prey type selection, but also by prey size selection, as homeana is considerably smaller than erosa both in Nigeria (Luiselli, 2003) and in Cameroon (Lawson, 2001), and differences in relative body sizes are well known to reduce competition intensity among coexisting species (Pianka, 1986). In this regard, it must be noticed that $K$. belliana has approximately the same average body size as $K$. homeana (Vetter, 2002).

As in my study, all species of Kinixys have been reported to be omnivorous that eat on both fungi, plants, and invertebrates (Villiers, 1958; Blackwell, 1968; Bertram, 1979; Broadley, 1989a, 1989b, $1989 \mathrm{c}$ ), but the only detailed data have been provided for K. spekii (Hailey, 1997, 1998; Hailey et al., 1997, 1998, 2001). It is supposed that the consumption of both fungi and arthropods by Kinixys species is due to the presence of chitinase in this genus (Hailey et al., 1997). In general, my data on Niger Delta species are fully consistent with those reported by Hailey and colleagues for $K$. spekii. This latter is, however, a species of more arid environment.

In conclusion, my study demonstrates that interspecific competition is potentially an important force in structuring the coexistence of sympatric hingeback tortoises in the rainforests of tropical Africa, and that, as a response to it, two potential competitors ( $K$. homeana and $K$. erosa) evolved diverging foraging strategies (extreme versus moderate dietary generalist habits) in both wet and dry sdasons. Removal experiments, currently in progress, will serve to demonstrate what are the precise mechanisms of it.

\section{Acknowledgements}

The "Kinixys conservation ecology project" was conducted under the economic support of Chelonian Research Foundation through The Linnaeus Fund (Annual Turtle Research Grants Program; year 1999-2000-2001). I am gratefully indebted to some companies of the ENI group (Snamprogetti S.p.A., Aquater S.p.A.), Demetra s.r.l., Ecosystem s.r.l., Italian Foundation of Vertebrate Zoology, and T.S.K.J. Nigeria Ltd., which supported some phases of my continued research in Nigeria. Adrian Hailey kindly sent his Kinixys research papers to me. F.M. Angelici, E. Politano, C.O. Ebin, Z. Tooze, E.A. Eniang, and G.C. Akani were of invaluable help in the field, and also commented upon the present report. Two anonymous referees critically reviewed a early draft.

\section{References}

Allanson M, Georges A. 1999. Diet of Elseya purvisi and Elseya georgesi (Testudines: Chelidae), a sibling species pair of freshwater turtles from eastern Australia. Chel. Cons. Biol. 3: 473-477.

Baard EHW. 1997. The dynamics of two sympatric tortoise communities in a stressful environment. In: Van Abbema J, ed. Conservation, Restoration, and Management of Tortoises and Turtles - An International Conference. New York Turtle and Tortoise Society, New York: 324-329.

Barbault R. 1977. Structure et dynamique d une herpétocénose de savane (Lamto, Cote-d Ivoire). Geo. Ecol. Trop. 1: 309334.

Barbault R. 1991. Ecological constraints and community dynamics: Linking community patterns to organismal ecology. The case of tropical herpetofaunas. Acta Oecol. 12: 139-163.

Barbault R, Ortega A, Maury ME. 1985. Food partitioning and community organization in a mountain lizard guild of Northern Mexico. Oecologia 65: 550-554.

Barbault R, Stearns SC. 1991. Towards an evolutionary ecology linking species interactions, life-history strategies and community dynamics: An introduction. Acta Oecol. 12: 3-10.

Bertram BCR. 1979. Home range of a hingeback tortoise in the Serengeti. Afr. J. Ecol. 17: 241-244.

Blackwell K. 1968. Kinixys species eating giant land snail. Brit. J. Herpetol. 4: 42.

Broadley DG. 1989a. Kinixys belliana, Bell's hinged tortoise. In: Swingland IR, Klemens MW, eds. The conservation biology of tortoises. IUCN Species Survival Commission, Gland: 49-55.

Broadley DG. 1989b. Kinixys erosa, serrated hinged tortoise. In: Swingland IR, Klemens MW, eds. The conservation biology of tortoises. IUCN Species Survival Commission, Gland, pp. 56-57.

Broadley DG. 1989c. Kinixys homeana, Home's hinged tortoise. In: Swingland IR, Klemens MW, eds. The conservation biology of tortoises. IUCN Species Survival Commission, Gland: 58-59.

Capizzi D, Luiselli L. 1996. Feeding relationships and competitive interactions between phylogenetically unrelated predators (owls and snakes). Acta Oecol. 17: 265-284.

Connell JH. 1983. On the prevalence and relative importance of interspecific competition: evidence from field experiments. Am. Nat. 122: 661-696.

Ernst CH, Barbour RW. 1989. Turtles of the World. Smithsonian Institution Press, Washington D.C.

Hailey A. 1995. Diet and food preferences of two South- 
African tortoises: the implications for niche separation. South-Afr. J. Wildl. Res. 25: 65.

Hailey A. 1997. Digestive efficiency and gut morphology of omnivorous and herbivorous African tortoises. Can. J. Zool. 75: 787-794.

Hailey A. 1998. The specific dynamic action of the omnivorous tortoise Kinixys spekii in relation to diet, feeding pattern, and gut passage. Physiol. Zool. 71: 57-66.

Hailey A, Chidavaenzi RL, Loveridge JP. 1998. Diet mixing in the omnivorous tortoise Kinixys spekii. Funct. Ecol. 12: 373-385.

Hailey A, Coulson IM, Chidavaenzi RL. 1997. Fungus eating by the African tortoise Kinixys spekii. J. Trop. Ecol. 13: 469-474.

Hailey A, Coulson IM, Mwabvu T. 2001. Invertebrate prey and predatory behaviour of the omnivorous African tortoise Kinixys spekii. Afr. J. Ecol. 39: 10-17.

Hurlbert SH. 1984. Pseudoreplication and the design of ecological field experiments. Ecol. Monogr. 54: 187-211.

Iverson JB. 1992. A Revised Checklist with Distribution Maps of the Turtles of the World. Privately Printed, Richmond.

Jackson DR. 1988. Reproductive strategies of sympatric freshwater emydid turtles in northern peninsular Florida. Bull. Florida State Mus. Biol. Sci. 33: 113-158.

Jaksic FM. 1982. Inadequacy of activity time as niche difference: the case of diurnal and nocturnal raptors. Oecologia 52: 171-175.

Kennett R, Tory O. 1996. Diet of two freshwater turtles, Chelodina rugosa and Elseya dentata (Testudines: Chelidae) from the wet-dry tropics of northern Australia. Copeia 1996: 409-419.

Lawson DP. 2000. Local harvest of hingeback tortoises, Kinixys erosa and $K$. homeana, in southwestern Cameroon. Chel. Cons. Biol. 3: 722-729.

Lawson DP. 2001. Morphometrics and sexual dimorphism of the hinge-back tortoises Kinixys erosa and Kinixys homeana (Reptilia: Testudinidae) in southwestern Cameroon. Afr. J. Herpetol. 50: 1-7.

Lagler KF. 1943. Food habits and economic relations of the turtles of Michigan with special reference to fish management. Amer. Midl. Natur. 80: 559-562.

Legler JM. 1976. Feeding habits of some Australian shortnecked tortoises. Vict. Nat. 93: 40-43.

Licht P, Dawson WR, Shoemaker VH, Main AR. 1966. Observations on the thermal relations of western Australian lizards. Copeia, 1966: 97-110.

Luiselli L. 2003. Comparative abundance and population structure of sympatric Afrotropical tortoises in six rainforest areas: the differential effects of "traditional veneration" and of "subsistence hunting" by local people. Acta Oecol. 24: in press.

Luiselli L, Akani GC, Capizzi D. 1998. Food resource partitioning of a community of snakes in a swamp-rainforest of south-eastern Nigeria. J. Zool. Lond. 246: 125-133.

Luiselli L, Akani GC, Angelici FM. 2002. Comparative feeding strategies and dietary plasticity of the sympatric cobras Naja melanoleuca and Naja nigricollis, in three diverging Afrotropical habitats. Can. J. Zool. 80: 55-63.
Luiselli L, Politano E, Akani GC. 2003. Seasonal incidence, sex-ratio, and population cohorts of hinge-back tortoises (genus Kinixys) in the wild and in bush-meat markets of the Niger Delta, southern Nigeria: Are human predation effects random? Rev. Ecol. (Terre et Vie) 58: 243-248.

Luiselli L, Politano E, Angelici FM. 2000. Ecological correlates of the distribution of terrestrial and freshwater chelonians in the Niger Delta, Nigeria: A biodiversity assessment with conservation implications. Rev. Ecol. (Terre et Vie) 55: 3-23.

Mathur D, Silver CA. 1980. Statistical problems in studies of temperature preferences of fishes. Can. J. Fish. Aquat. Sci. 37: 733-737.

Moll D. 1990. Population sizes and foraging in a tropical freshwater stream turtle community. J. Herpetol. 24: 48-53.

Ojonugwa OS. 1986. A survey of wildlife in bushmeat markets in Rivers and Imo State, Nigeria. Unpublished B. Sc. Thesis, Rivers State University of Science and Technology, Port Harcourt.

Pianka ER. 1973. The structure of lizard communities. Annu. Rev. Ecol. Syst. 4: 53-74.

Pianka ER. 1975. Niche relations of desert lizards. In: Cody ML and Diamond JM, eds, Ecology and Evolution of Communities. Belknap Press, Cambridge (USA): 292-314.

Pianka ER. 198̈6. Ecology and Natural History of Desert Lizards. Princeton University Press, Princeton.

Pritchard PCH. 2001. Observations on body size, simpatry, and niche divergence in softshell turtles (Trionychidae). Chel. Cons. Biol. 4: 5-27.

Sammartano DW. 1995. Spatial, dietary and temporal niche parameters of two species of box turtles (Terrapene) in microsimpatry. Box Turtle Res. Cons. Newsletter 4: 11.

Schoener TW. 1968. The Anolis lizards of Bimini: resource partitioning in a complex fauna. Ecology 49: 704-726.

Schoener TW. 1974. Resource partitioning in ecological communities. Science 185: 27-39.

Schoener TW. 1982. The controversy over interspecific competition. Am. Sci. 70: 586-595.

Schoener TW. 1983. Field experiments on interspecific competition. Am. Nat. 122: 240-285.

Schoener TW. 1985. Some comments on Connell's and my

- reviews of field experiments on interspecific competition. Am. Nat. 125: 730-740.

Scott NJ Jr, Campbell HW. 1981. A chronological bibliography, the history and status of studies of herpetological communities, and suggestions for future research. In: Scott NJ Jr, ed., Herpetological Communities, United States Department of the Interior, Fish and Wildlife Service, Washington D.C: 221-239.

Stone PA, Hauge JB, Scott AF, Guyer C, Dobie JL. 1993. Temporal changes in two turtle assemblages. J. Herpetol. 27: 13-23.

Strong DR, Simberloff D, Abele LG, Thistle AB (eds). 1984. Ecological Communities: Conceptual Issues and the Evidence. Princeton University Press, Princeton.

Teran AF, Vogt RC, Gomez MFS. 1995. Food habits of an assemblage of five species of turtles in the Rio Guapore, Rondonia, Brazil. J. Herpetol. 29: 536-547. 
Toft CA. 1985. Resource partitioning in amphibians and reptiles. Copeia 1985: 1-21.

Underwood T. 1986. The analysis of competition by field experiments. In: Kikkawa J, Anderson DJ, eds., Community Ecology: Pattern and Process, Blackwell, Oxford, pp. 240268.

Vetter H. 2002. Turtles of the World. Vol. I. Africa, Europe, and Western Asia. Edition Chimaira, Frankfurt am Main.

Villiers A. 1958. Tortues et crocodiles de l'Afrique noire Francaise. Initiations Africaines XV, IFAN, Dakar.
Vogt RC. 1981. Food partitioning among three species of Graptemys. Amer. Midl. Natur. 105: 102-111.

Vogt RC, Guzman S. 1988. Food partitioning in a neotropical freshwater turtle community. Copeia 1988: 37-47.

Williams TA, Christiansen JL. 1981. The niches of two sympatric softshell turtles, Trionyx muticus and Trionyx spiniferus, in Iowa. J. Herpetol. 15: 303-308.

Accepted: 26 May 2003 